\title{
Exploring the Benefits of Cloud Computing Paradigm in Education Sector
}

\author{
Ramneek Kaur \\ Assistant Professor \\ P.G. Department of Computer Science \\ G.S.S.D.G.S. Khalsa College Patiala
}

\author{
Sawtantar Singh, Ph.D. \\ Head \\ Department of Computer Science \\ Bhai Maha Singh College of Engineering Muktsar
}

\begin{abstract}
Cloud computing is leading IT revolutionary technology (Gartner - Gartner Newsroom,2010) and considered as an extension to the significant achievements of grid, virtualization, Web 2.0 and Service Oriented Architecture (SOA) technologies and the convergence of these technologies. It uses the internet to deliver different computing services including hardware, programming environments and software while keeping users unaware of underlying location and infrastructure. This research paper discusses the potential benefits of cloud computing for delivering educational services in developing countries as well as sheds light on the ICT based initiatives taken and need of cloud based education delivery in the state of Punjab.
\end{abstract}

\section{Keywords}

Cloud Computing, Internet, Satellite, ICT tools etc.

\section{INTRODUCTION}

Nowadays Cloud Computing is the most rapid technology which combines services, servers and applications all in one location through the internet. Cloud Computing is a technology that provides storage for data or is a resource for data online. The user will pay as per his use of those resources (Lin et al., 2014) [10].

As Cloud computing is still an evolving paradigm so its definitions, underlying technologies, issues etc. are refined in a spirited debate by the public and private sectors.

\begin{tabular}{|c|c|c|}
\hline Sno & $\begin{array}{l}\text { Definition of Cloud } \\
\text { Computing }\end{array}$ & \\
\hline 1. & $\begin{array}{l}\text { "Cloud computing can be } \\
\text { defined as a new style of } \\
\text { computing in which } \\
\text { dynamically scalable and } \\
\text { often virtualized resources } \\
\text { are provided as a services } \\
\text { over the Internet". }\end{array}$ & (Furht ,2010)[5]. \\
\hline 2. & $\begin{array}{l}\text { "A large-scale distributed } \\
\text { computing paradigm that is } \\
\text { driven by economies of } \\
\text { scale, in which a pool of } \\
\text { abstracted, virtualized, } \\
\text { dynamically scalable, } \\
\text { managed computing power, } \\
\text { storage, platforms, and } \\
\text { services are delivered on } \\
\text { demand to external } \\
\text { customers over the Internet". }\end{array}$ & $\begin{array}{l}\text { (Foster, } \begin{array}{r}\text { Zhao, } \\
\text { Raicu, \& } \\
\text { 2008)[6]. }\end{array} \\
\end{array}$ \\
\hline
\end{tabular}

\begin{tabular}{|c|c|c|}
\hline 3. & $\begin{array}{l}\text { "A broad array of web-based } \\
\text { services aimed at allowing } \\
\text { users to obtain a wide range } \\
\text { of functional capabilities on } \\
\text { a "pay-as-you-go" basis that } \\
\text { previously required } \\
\text { tremendous hardware } \\
\text { /software investments and } \\
\text { professional skills to } \\
\text { acquire. Cloud computing is } \\
\text { the realization of the earlier } \\
\text { ideals of utility computing } \\
\text { without the technical } \\
\text { complexities or complicated } \\
\text { deployment worries". }\end{array}$ & $\begin{array}{l}\text { (Twenty Experts } \\
\text { Define } \\
\text { Computing, } \\
\text { 2008)[15]. }\end{array}$ \\
\hline 4. & $\begin{array}{l}\text { "Cloud computing is a } \\
\text { model for enabling } \\
\text { ubiquitous, convenient, on- } \\
\text { demand network access to a } \\
\text { shared pool of configurable } \\
\text { computing resources (e.g., } \\
\text { networks, servers, storage, } \\
\text { applications, and services) } \\
\text { that can be rapidly } \\
\text { provisioned and released } \\
\text { with minimal management } \\
\text { effort or service provider } \\
\text { interaction". }\end{array}$ & $\begin{array}{l}\text { (Mell and Grance } \\
\text {,2011)[11]. }\end{array}$ \\
\hline
\end{tabular}

The cloud model has five essential characteristics- on demand self-service, broad network access, resource pooling, rapid elasticity and measured service. It also lists three service models as -software as service, platform as service, infrastructure as service and the four deployment models private, public ,community and hybrid (Mell and Grance ,2011)[11].

\section{EDUCATION AND CLOUD COMPUTING}

India needs to focus on its school and college education if it has to accelerate its long-term growth rate. Technology has the potential to create new models of learning and achieve impact at large scale. It is need of hour to invest in technology which will focus on hardware and software development across our school and higher education institutions. It is required to train educators to combine technology in their pedagogy for effective classroom delivery. The development of high-quality Massive Online Open Courses (MOOCs) and other personalized learning resources in local languages can go a long way in balancing the tension between equity and excellence at scale [3]. Cloud Computing technology provides 
various computer based applications to users without the need to purchase or install software on their local computers or servers. Recently a new trend is opted by Educational institutions to use existing applications through cloud. The services like messaging, mail, collaboration tools, office applications and platform applications are provided with no cost by Cloud based platforms (Jones and Sclater, 2010)[9].This technology will help the academic institutions to reduce IT infrastructure and cost with the usage of applications hosted on cloud. It has made possible to remove the time and space obstacles to facilitate learning for students via internet. The Internet subscriber base in the country as on 31st March 2012 stood at 22.86 million, registering an annual growth rate of about $16.19 \%$. The total broadband subscriber base has reached 13.81 million as on 31st March 2012, with growth of $16.15 \%$. As on 31st March 2012, the wireless rural [Mobile and WLL (F)] market has reached the 323.27 million mark as against 273.54 million as on 31st March 2011. As per the Performance Indicator Report, $35.17 \%$ of total wireless subscribers are now in rural areas. The rural subscriber base is progressively increasing (India Country Report, 2013)[12].These statistics convinces to use internet based techniques in India for delivering educational services to individuals irrespective of time and space constraints.

\section{BENEFITS OF CLOUD BASED EDUCATION}

The number of factors which convinces the adoption of cloud computing for providing educational services to the Indian institutions includes:

\subsection{Quality of teaching}

India has been among the fastest-growing economies in the world in the last decade. The low-quality education is crippling India's growth as its emerging workforce is unable to cope with the demands of a 21 st-century economy [3].For economic growth and development of country all the children should have access to equal access and quality education. Cloud technology enables education institutions to focus on its core activities and ensure smooth operations and improving the quality of the teaching course content (Gupta, 2012) [8].

\subsection{Reduced investment}

The educational institutions now have an option to leverage many SaaS, PaaS and IaaS based offerings in the market without the need to invest in procurement and maintenance of infrastructure [1]. It is convenient for students to execute learning applications from cloud through the various available gadgets in the market such as Personal computers, mobile phones, tablets having minimum configuration with internet connectivity.

\subsection{Overcome the shortage of Skilled Teachers}

With cloud technology, remote classrooms can help to run multiple classrooms through a small group of teachers and will help to overcome the problem of lack of skilled teachers[1].

\subsection{Standardized course content}

Courses delivered over cloud through a central location will lead to a standard content delivery to multiple remote virtual classrooms[1]. It lead consistency in learning or training as at different locations students are getting the same study material.

\subsection{Back Up and Storage}

It provides backup and storage for the content and hence avoiding the data loss in case of system crashes. The Cloud allows its users to store and access almost all types of content and data such as audio/video, applications etc. As data storage and accessing is through cloud and user has to pay as use basis and hence eliminates expenses for memory.

\subsection{Ease of use within collaborative environment}

It is easy for multiple students to work on same project using email, online forums irrespective of their physical location and time. Moreover cloud data can easily be accessed whenever needed through latest ICT tools. With this feature, group projects and or collaborative lesson plans can be optimized for both teachers and students (Weaver ,2013) [16].

\subsection{Enhance administrative functionality of Institutes}

All the software's are automatically updated in cloud source which facilitate the learners with latest updates instantly. Teachers and the administrative staff can focus on the core functions of the institution instead of futile efforts on IT infrastructure and the applications set-up [1].As result all the administrative activities will be performed in faster and effective manner.

\subsection{Encouragement and Motivation}

The cloud based learning will increase excitement and motivation in learning which encourage the students to take responsibility for their learning and enhances self knowledge and self confidence.

\section{NEED OF DELIVERING CLOUD BASED EDUCATION IN PUNJAB STATE}

Government has taken initiative to improving the education level and interest of students towards learning. Presently in Government schools of Punjab receive only terminals (ROTs) are being used to gain satellite based education services. The students are able to attend recorded lectures on LCD in allotted time according to decided schedule .Even many school do not have working infrastructural support to avail these facilities. Earlier Satellite Interactive Terminals (SITs) were used to provide interactive learning. Students were able to ask or send queries to sending station. This mechanism helped a lot in providing quality education and learning through audio and video based lectures [14]. Now there is constant increase in popularity of smart classes as education with such environment is suitable for all kinds of students. Each student has different level of understanding and use of such modern technologies makes learning easier for all students. It also enhances Student- Teacher communication. According to revised ICT school scheme each State Government/Union Territory would convert one school per district into a smart school subject to availability of funds. Each smart school would get 25 lakhs of grant [13]. Although technology can create a new opening for the education sector but the cost factor for establishing smart education comes with high cost education. Also the State Government of Punjab has announced its plan on setting up 795 new computer labs with facility of generator sets and broadband internet connections with unlimited download facility under the Information and Communication Technology (ICT) project in the state [2]. In spite of such initiative there are some hurdles that hinder the 
growth of education in rural areas as compared to urban areas such as:

Poor connectivity: There are total 12673 villages in Punjab and most villages have poor connectivity due to lack of proper transportation. Therefore majority of students cannot avail the facilities provided by government schools on regular basis.

Lack of proper infrastructure: Still some schools are lacking of proper classrooms, teaching aids and even basic facilities like clean toilets which altogether demotivate the students from learning.

Low wages: In rural educational centers teachers are getting low salaries and has led lack of attention towards their duties and students .Also in poor families each member is supposed to earn therefore the parents don't send their children to schools for getting education which is even free of cost.

All these reasons are causing a gap between the rural and urban education. So some initiatives using advanced ICT's should be required for creating a platform to sort these disparities. Cloud computing in education gives better choice and flexibility for providing software and platform services according to the requirement of the educational institutions. EAAS (Education as a service)will help to deliver advance software, computer lab resources, scientific software's and tools as a service to researchers, enable scientists with the computational powers to perform complex processor oriented task in real time affordable and high end educational services to educational institutions (Deepa N. \& Sathiyaseelan R. 2012)[4]

\section{CONCLUSION}

Educational environment is going to take a new shape because the $21^{\text {st }}$ century students are growing up with applications like Facebook, Twitter etc. The use of latest ICT gadgets like Smart phones, Tablets, iPods and Notebooks etc. having internet connection are increasing day by day. These gadgets can be embedded into teaching-learning process to increase the involvement of student-teacher in learning activities. As conventional form of education delivery pattern (like face to face) is now not able to fulfill demands of new century students. The latest ICT tools and technologies can be used to resolve the technical issues in learning process like dynamic content creation, to overcome the storage and processing requirements and many more. Through this paper it is suggested that a cloud based application should be created which combines technology tools with the innovative and inspirational content to fulfill the demand of quality of education. The major hurdles that cloud technology is facing includes data privacy issues, lack of awareness of cloud in India, inadequate bandwidth etc. Cloud service providers should take initiative to organize seminars \& workshops in order to spread awareness about the latest advancements of cloud computing in educational institutions and other organizations.

\section{REFERENCES}

[1] [Online]

Available:http://www.pwc.in/en_IN/in/assets/pdfs/public ations/2014/cloud-computing discussion-paper-for-theeducation-automotive-and-it-ites-sector.pdf

[2] [Online]Available: http://www.cityairnews.com/content/ every-student-be-made-digitally- literate
[3] [Online]Available:http://businesstoday.intoday.in/story/f ocus-school-college-education- for-gdp- growth- ashishdhawan /1/213470.html

[4] Deepa N. \& Sathiyaseelan R.(2012) " The Cloud and the Changing Shape of Education -Eaas (Education as a Service)" International Journal of Computer Applications, Vol. 42-No.5, ISSN: 0975 -8887, 4-7.

[5] Furht B. (2010), "Cloud Computing Fundamentals ",Chapter 1,Springer,pp 3-19.

[6] Foster I., Zhao Y., Raicu I. \& Lu S. Y. (2008) "Cloud computing and grid computing 360-degree compared". Proceedings of the Grid Computing Environments Workshop (GCE'08), Austin, TX

[7] Gartner -Gartner Newsroom (2010) http://www.gartner.com/it/page.jsp?id=1210613.Accesse d on July 13, 2010.

[8] Gupta AK. (2012) "A Comparative Study of Approaches Available to Support the Impact Study of Satellite Supported one way Educational System". ARPN Journal of Science and Technology Vol. 2, No.. 10, ISSN :22257217.

[9] Jones Ch. and Sclater N. (2010): Learning in an age of digital networks. International Preservation News, 55,610 http://oro.open.ac.uk/24116/2/learning_in_an_age.pdf.

[10] Lin, Jenn-Wei, Chien-Hung Chen, and Chi-Yi Lin(2014)"Integrating QoS awareness with virtualization in cloud computing systems for delaysensitive applications." Future Generation Computer Systems.

[11] Mell P. \& Grance T.(2011)"NIST Cloud Computing Definition" National Institute of Standards and Technology Special publication 800-145pages.

[12] Report No. 22 of 2013 Chapter III Department of space Retrieved from http://saiindia.gov.in/english/home/Our_Products/Audit_ Report/Government_Wise/union_audit/ recent_reports/union_compliance/2013/SD/Report_22/Re port_22.html

[13] Revised $\quad$ ICT@School Scheme http://ictschools.gov.in/sites/default/files/pdf/ICTscheme. pdf

[14] SAARC Development Goals-India Country Report,2013 Retrieved from http://www.mospi.nic.in/./SAARC_Development_Goals_ \%20India_Country_Report

[15] Twenty Experts Define Cloud Computing (2008). SYSCON Media Inc., retrieved from http://cloudcomputing.sys-con.com/read/612375_p.htm. Accessed on July 13,2010

[16] Weaver D.(2013)“Six Advantages of Cloud Computing in Education" http://www.pearsonschoolsystems.com/blog/?p=1507\#st hash.HKm68GLE.dpbs 